Article

\title{
Modeling Past, Present, and Future Urban Growth Impacts on Primary Agricultural Land in Greater Irbid Municipality, Jordan Using SLEUTH (1972-2050)
}

\author{
Rana N. Jawarneh 1,2 (D) \\ Department of Geography, Yarmouk University, Irbid 21163, Jordan; rnjawarneh@yu.edu.jo \\ Applied Geoinformatics Laboratory, Yarmouk University, Irbid 21163, Jordan
}

check for updates

Citation: Jawarneh, R.N. Modeling Past, Present, and Future Urban Growth Impacts on Primary

Agricultural Land in Greater Irbid Municipality, Jordan Using SLEUTH (1972-2050). ISPRS Int. J. Geo-Inf. 2021, 10, 212. https://doi.org/ $10.3390 /$ ijgi10040212

Academic Editors: Wolfgang Kainz and Maria Antonia Brovelli

Received: 20 January 2021

Accepted: 24 March 2021

Published: 1 April 2021

Publisher's Note: MDPI stays neutral with regard to jurisdictional claims in published maps and institutional affiliations.

Copyright: (C) 2021 by the author. Licensee MDPI, Basel, Switzerland. This article is an open access article distributed under the terms and conditions of the Creative Commons Attribution (CC BY) license (https:// creativecommons.org/licenses/by/ $4.0 /)$
Abstract: Urban expansion and loss of primarily agricultural land are two of the challenges facing Jordan. Located in the most productive agricultural area of Jordan, Greater Irbid Municipality (GIM) uncontrolled urban growth has posed a grand challenge in both sustaining its prime croplands and developing comprehensive planning strategies. This study investigated the loss of agricultural land for urban growth in GIM from 1972-2050 and denoted the negative consequences of the amalgamation process of 2001 on farmland loss. The aim is to unfold and track historical land use/cover changes and forecast these changes to the future using a modified SLEUTH-3r urban growth model. The accuracy of prediction results was assessed in three different sites between 2015 and 2020. In 43 years the built-up area increased from $29.2 \mathrm{~km}^{2}$ in 1972 to $71 \mathrm{~km}^{2}$ in 2015. By 2050, the built-up urban area would increase to $107 \mathrm{~km}^{2}$. The overall rate of increase, however, showed a decline across the study period, with the periods of 1990-2000 and 2000-2015 having the highest rate of built-up areas expansion at 68.6 and $41.4 \%$, respectively. While the agricultural area increased from $178 \mathrm{~km}^{2}$ in 1972 to $207 \mathrm{~km}^{2}$ in 2000, it decreased to $195 \mathrm{~km}^{2}$ in 2015 and would continue to decrease to $188 \mathrm{~km}^{2}$ by 2050. The district-level analysis shows that from 2000-2015, the majority of districts exhibited an urban increase at twice the rate of 1990-2000. The results of the net change analysis of agriculture show that between 1990 and 2000, 9 districts exhibited a positive gain in agricultural land while the rest of the districts showed a negative loss of agricultural land. From 2000 to 2015, the four districts of Naser, Nozha, Rawdah, and Hashmyah completely lost their agricultural areas for urbanization. By 2050, Idoon and Boshra districts will likely lose more than half of their high-quality agricultural land. This study seeks to utilize a spatially explicit urban growth model to support sustainable planning policies for urban land use through forecasting. The implications from this study confirm the worldwide urbanization impacts on losing the most productive agricultural land in the outskirts and consequences on food production and food security. The study calls for urgent actions to adopt a compact growth policy with no new land added for development as what is available now exceeds what is needed by 2050 to accommodate urban growth in GIM.

Keywords: urban sprawl; land conversion; Cellular Automata models; Greater Irbid Municipality; agricultural land loss; SLEUTH-3r; Jordan

\section{Introduction}

Since the late 20th century, urbanization has become one of the leading anthropogenic activities transforming the Earth's surface and consuming agricultural land; by 2000 about $88 \%$ of these areas were destroyed by urban conversion [1-3]. Cities are home to more than 54\% of the world's population, and by 2050 this percentage is expected to reach $66 \%$ [4]. To provide a favorable-living environment and housing units for the growing population, cities have rapidly grown beyond their peripheries, mostly on the primary agricultural lands [5]. A low-intensity urban sprawl pattern has evolved as the reliance on the automobile and the desire for suburban living increase. The spatial extent of urban areas worldwide is expanding twice as fast as their population [6,7]. 
Although urban sprawl was first recognized as an American phenomenon, it has become global with different levels of adaptations between and among the high and lowincome countries [8-10]. High-income countries have demonstrated better adaptation policies (i.e., compact planning policies and zoning policies) to minimize the negative impacts of sprawl, especially on primary farmlands and valuable soils [11-13]. However, low-income countries struggle with sprawl as their urban population increases at rates much higher than their economic development rate [14-20]. In these countries, urbanization governance lacks sustainable planning strategies while neglecting available natural resources (i.e., soils, physiography, and vegetation) as a baseline for land management and land-use conversion [21,22]. As a result, consumption of farmland for urbanization has had profound impacts on the food security of low-income countries [23] and has become a grand challenge, especially for the poorer countries suffering from scarcity of natural resources.

To properly manage and track land conversions and urban encroachment on primary lands it is critical to map urban dynamics over a long time and forecast future urban development under certain exclusion variables using spatially explicit models such as Cellular Automata (CA) urban growth models. They are a good example of the most popular models in urban mapping due to their capabilities for viewing urban areas as dynamic environments featuring the complex processes embedded within urban systems [24,25]. Such models can avoid many shortcomings of traditional urban growth models due to their base of the cell, state, neighborhood, and transition rules [26]. The SLEUTH (Slope, Land cover, Exclusion, Urban, Transportation, and Hillshade) model simulates four types of urban growth: spontaneous growth, new spreading center growth, edge growth, and road-influenced growth. These growth types are applied sequentially during each growth cycle and controlled through the interactions of growth coefficients: dispersion, breed, spread, slope resistance, and road gravity $[12,27,28]$.

Since its initial development in 1997, SLEUTH has undergone numerous technical modifications, since its initial days, to reach its current sophisticated state [29,30]. SLEUTH's source code was revised to reduce computation time and sensitivity. The development of the Optimal SLEUTH Metric (OSM) helped in determining the best goodness of fits measure [24]. A parallel version of the model (pSLEUTH) was developed using a parallel raster processing programming library (pRPL) to enhance SLEUTH's capabilities of processing massive raster datasets in a shorter computation time [30]. A significant improvement was made to the SLEUTH model and a modified version (SLEUTH-3r) [28]. SLEUTH-3r can capture dispersed settlement patterns more efficiently through modifying the diffusion multiplier value. In this modified version, the user can interactively set the diffusion coefficient multiplier after being static (0.005) in the early version. Furthermore, SLEUTH-3r creates new tabular files, including differences and ratio metrics (Population Fractional Difference (PFD) and Cluster Fractional Difference (CFD)), that directly compare the modeled variable with the observed variable for all control sets. These metrics allow for using two historic urban extents instead of four and can be used as an alternative for measures of fit used to evaluate simulated urban in the calibration phase.

A countless number of studies worldwide have applied SLEUTH to capture and predict urban dynamics [31]. In the US, the model was intensively used within the metropolitan counties for many eastern, western, and southern cities [24,26,27,32]. In Europe, the model was implemented in many cities such as Lison and Porto [33], Helsinki (Finland), Bilbao (Spain), and Palermo (Italy) [34], and was used to model the impacts of urban growth on agriculture and natural land for the entire country of Italy [35] In the Middle East, many case-studies utilized SLEUTH to map and quantify urban changes for the cities of Mashad (Iran) [36], Cairo and Alexandria(Egypt) [37,38], Muscat (Oman) [39], and Sana'a (Yemen) [40].

With nearly $68 \%$ of its population reside in cities, the Arab region is recognized among the scarcest water and agricultural resources per capita in the world [41-43]. The Arab countries' unplanned urban expansion adds another challenge in promoting sustainable 
development and sustaining limited agricultural resources, especially farmlands. From 1970 to 2010, the Arab urban population grew four times, and the number is expected to double by 2050 [42]. Here, city planning is often challenged by the disconnection between national strategic planning cycles and spatial planning for urban development. This becomes more problematic when the Arab countries neglect the importance of proper management through balancing between available agricultural lands and conversion for urban use [44]. Nevertheless, and due to increasing conversion rates of farmlands to urbanization, countless efforts have been paid towards modeling long-term land-use/cover dynamics, in general, and urbanization, in particular, in these countries [44-47]. Jordan is categorized as a food deficit Arab country, where $0.5 \%$ of all households suffer from food insecurity. Jordan's arable area has undergone considerable decline since 1975 mainly due to rapid urban growth and land degradation [48-50]. Although the contribution of the agricultural sector to the GDP is small, farming remains a major source of food for nearly $25 \%$ of Jordan's poor [51,52]. While numerous studies were conducted to establish a linkage between urbanization and agricultural land consumption, the focus was yet on the capital city of Amman [53-56].

Located to the north of Amman in the most fertile and productive agricultural zone of Jordan, Irbid city was neglected for years. In recent years and as land-use/cover began to change dramatically, built-up urban area rapidly has grown on the productive peripheral farmlands, forming a major metropolitan area in the north. To facilitate the problem of governance of such a vast area, the number of municipalities and village councils around the city of Irbid were amalgamated to form what is known today as the Greater Irbid Municipality [57]. Accordingly, the municipal boundary of Irbid city was adjusted resulting in integrating agriculturally dominant rural districts to the city limits. Since 2001, the GIM area has undergone significant land cover changes to support the growing urban population resulting from (1) economic development (2) domestic rural-urban migration, (3) changing demographic structure, (4) changing lifestyle, and (5) the influx of Syrian refugees during the Arab Spring of 2011 [58].

While numerous case-studies investigated urban growth in Irbid using remote sensing and GIS [59-63], no study has yet used the SLEUTH model to predict urban dynamics and quantify the past, present, and future urban expansion on agricultural land of Jordan. The SLEUTH model is applied for the first time in Jordan, providing a robust approach for making long-term sustainable urban planning strategies that integrate spatially explicit models and geospatial technologies. In this study, the impact of past, present, and future urban development patterns and agricultural land consumption across a $324 \mathrm{~km}^{2}$ GIM area are examined. These transformations are analyzed at the district level for the first time to highlight the most affected districts and their agricultural values. The GIM was selected as a study area because (1) nearly $40 \%$ of Jordan's primary croplands located in Irbid, (2) it is the second-fastest-growing urban area in the country, (3) it has been experiencing rapid socioeconomic and demographic transformations, and (4) its zoning and urban planning policies are not well designed, not fully enforced, and their sustainability perspectives are not pronounced.

\section{Materials and Methods}

\subsection{Study Area}

\subsubsection{Environmental Settings}

Greater Irbid Municipality (GIM) stretches over the most productive agricultural land in Jordan, where the mild Mediterranean climate is dominant. The climate is the semiarid Mediterranean with hot summers $\left(27^{\circ} \mathrm{C}\right)$, and mild winters $\left(10^{\circ} \mathrm{C}\right)$ with moderate rainfall $(47 \mathrm{~cm})$. Its relatively level topography made it suitable for settlement and farming activities. The major land covers are Urban and Agriculture. Rain-fed farming mainly dominates the eastern and southeastern parts of the study area where the Vertisols are the predominant soil type (Figure 1). Vertisols cover more than $60 \%$ of the study area and are found in the undulating eastern and southeastern plains. Vertisols are deep fertile soils 
containing high clay [64]. Inceptisols are found in the less fertile parts of GIM along the northern and western rolling hills of GIM.

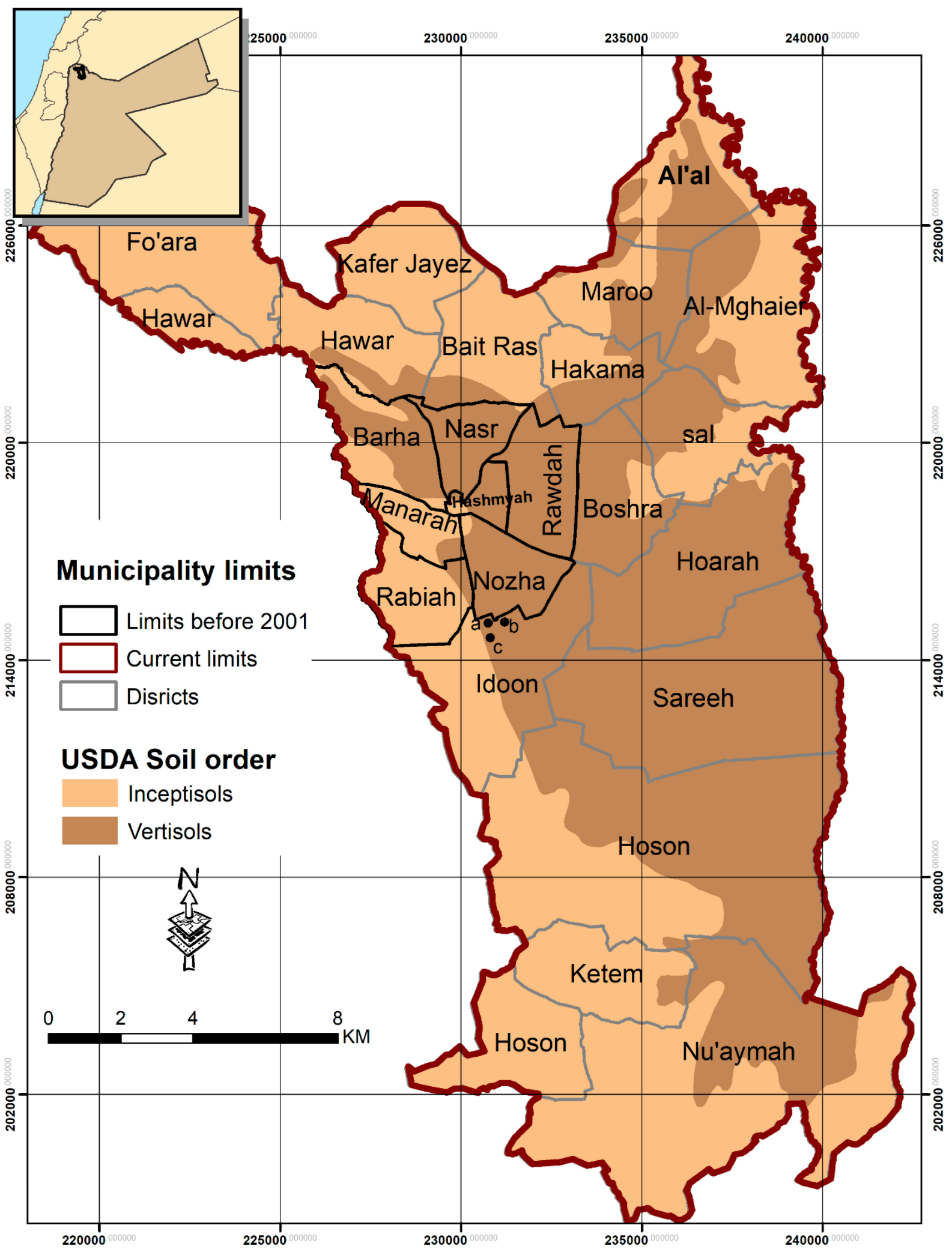

Figure 1. Greater Irbid Municipality (GIM) study area overlaid on top of the soil map. Points a, b, and c denote the three 6 sites visited for accuracy assessment of SLEUTH prediction results. 


\subsubsection{History of GIM Evolution}

Greater Irbid Municipality (GIM) is the second-largest populated metropolitan municipality in Jordan, after Amman, with a population estimate of 907,675 which represents nearly half of the Irbid governorate population [65]. It is located $80 \mathrm{~km}$ north of Amman on the Highland Plateau close to the Syrian boundaries, forming an important transportation and business hub not only in Jordan but in the entire region. Irbid city was established in 1884 with a total population of 1300 . It is considered one of the oldest cities, established in 1884 , and municipalities in Jordan that grew from a small village with a total population of 1300 surrounded by vast areas of high-quality farmland into a metropolitan agglomeration center in the 21st century. In its early development stages, urban areas expanded smoothly from their center around Al-Tal toward the surrounding wheat fields. That was until 1948 when the city, along with other Jordanian cities, received the first wave of Palestinian refugees. A new camp was established in 1950 on the northern edge of the city center [66]. The second wave of Palestinian refugees happened in 1967 and a new camp was built outside the city in Hoson town. Afterward, Irbid's urban area expanded substantially, and its population reached 112, 864 inhabitants. Since then, Irbid has represented the only modern city in northern Jordan attracting domestic migration from rural communities. Besides its strategic location and agricultural value, Irbid has become an educational elite center with the establishment of Yarmouk University and Jordan University for Science and Technology in 1976 and 1986, respectively. Nowadays, the metropolitan area of Greater Irbid Municipality covers an area of $324 \mathrm{~km}^{2}$ spreading over 23 municipal districts.

\subsection{Land Cover and Urban Data}

For land cover information and urban data, a historical land cover timeline was developed and compiled from different sources for the years: 1972, 1980, 2000, and 2015. The 1972 land cover map was developed by visually interpreting land cover types and manually digitizing them from a Landsat MSS scene (Path 187, Row 37) that was downloaded from the Landsat data portal (https:/ / www.usgs.gov/ core-science-systems/nli/landsat) (accessed on 16 April 2016) following a consistent mapping technique. The other land cover maps were extracted from the Jordan National Land Cover Database (JNLCD) product at $30 \mathrm{~m}$ resolution [67]. The JNLCD is the first decadal land cover database for Jordan that was developed using a total of 44 scenes for 4 decades (11 tiles in each year). These satellite remote sensing data (Table 1) were mostly cloud-free and were obtained during the growing season. They were geo-registered to Jordan Transfer Mercator (JTM) projection and radiometrically (surface reflectance) corrected.

Table 1. Landsat tiles used to develop the Jordan National Land Cover Database. [Source 67].

\begin{tabular}{cccc}
\hline Path/Row & Landsat Sensor & Acquisition Date & Cloud Coverage $\%$ \\
\hline 172/37 & TM5 \& OLI & June 1984; March 1991; April 1998; April 2014 & $0.0 ; 0.0 ; 0.0 ; 0.0$ \\
172/38 & TM5 \& OLI & April 1984, February 1991; March 1998; April 2014 & $0.0 ; 0.0 ; 0.0 ; 0.0$ \\
172/39 & TM5 \& OLI & June 1984; March 1991; April 1998; April 2014 & $0.0 ; 0.0 ; 0.0 ; 0.1$ \\
173/37 & TM5 \& OLI & April 1984, February 1991; March 1998; April 2014 & $10 ; 10 ; 20 ; 0.0$ \\
$173 / 38$ & TM5 \& OLI & August 1984; March 1991; May 1998; April 2014 & $0.0 ; 0.0 ; 0.0 ; 0.0$ \\
$173 / 39$ & TM5 \& OLI & April 1989; February 1991; March 1998; April 2014 & $0.0 ; 0.0 ; 0.0 ; 0.0$ \\
$173 / 40$ & TM5 \& OLI & April 1984; February 1991; March 1998; April 2014 & $0.0 ; 0.0 ; 0.0 ; 0.0$ \\
$174 / 37$ & TM5 \& OLI & April 1984; March 1991; April 1998; April 2014 & $60 ; 10 ; 0.0 ; 0.8$ \\
$174 / 38$ & TM5 \& OLI & April 1984; March 1991; April 1998; April 2014 & $40 * 30 * ; 0.0 ; 0.2$ \\
$174 / 39$ & TM5 \& OLI & April 1984; February 1991; April 1998; April 2014 & $10 ; 0.0 ; 0.0 ; 0.0$ \\
$174 / 40$ & TM5 \& OLI & April 1984; February 1991; April 1998; April 2014 & $10 ; 0.0 ; 0.0 ; 0.0$ \\
\hline
\end{tabular}

* The high cloud coverage was over the Mediterranean Sea, Lebanon, and Palestine parts of the scenes. 
A set of ancillary and derived spatial data (i.e., slope, potential land use map, soil map, and derived NDVI values) were used to help to delineate land cover types. Land cover classification methods used in developing the JNLCD dataset combined unsupervised with rule-based classifications to resolve the problem of spectral clusters with low separability. Thematic accuracy for the JNLCD dataset was performed for the 1980s and 2015s maps due to the availability of high-resolution reference data and were 94 and $90 \%$, respectively. For this study, the modified Anderson Level 1 JNLCD land cover legend was aggregated (Table 2) to enable comparison with other land cover maps that were developed for the study area. The JNLCD detailed agricultural-related land cover types, specifically, were aggregated to agricultural land.

Table 2. Land use/cover classes used in this study. Classification was based on modified Anderson Level I. Inclusive land cover classes from JNLCD and previous land cover maps for the study are noted.

\begin{tabular}{|c|c|c|c|}
\hline \multirow[b]{2}{*}{ Land Cover } & \multirow[b]{2}{*}{ Definition } & \multicolumn{2}{|c|}{ Inclusive Land Cover Classes } \\
\hline & & JNLCD & Al-Kofahi et al.'s \\
\hline Built-up areas & $\begin{array}{l}\text { High, medium, low intensity } \\
\text { developed areas, areas with a mixture } \\
\text { of constructed materials and vegetation. } \\
\text { Generally, impervious surfaces account } \\
\text { for } 20 \% \text { to } 100 \% \text { of the total cover. }\end{array}$ & Urban & Urban area \\
\hline Sparsely vegetated/Barren & $\begin{array}{l}\text { Open rangelands, non-cultivated areas, } \\
\text { dwarf shrubs, bare soils, sands, } \\
\text { quarries, mud flat, and wadi deposits. } \\
\text { Generally, areas with vegetation } \\
\text { accounts for less than } 10 \% \text { of } \\
\text { total cover. }\end{array}$ & Sparsely vegetated/Barren & Open land \\
\hline Agricultural land & $\begin{array}{l}\text { Rainfed areas cultivated with field } \\
\text { crops (wheat and barley), fallow lands; } \\
\text { Trees (mainly olive trees and fruit trees); } \\
\text { and Vegetables crops, orchards grown } \\
\text { under permanent irrigation } \\
\text { infrastructure and greenhouses. }\end{array}$ & $\begin{array}{c}\text { Rainfed croplands, orchards, } \\
\text { and irrigated agriculture }\end{array}$ & Green space \\
\hline
\end{tabular}

\subsection{Urban Growth Modeling}

\subsubsection{SLEUTH Inputs and Calibration}

The inputs used for SLEUTH-3r were: 1972, 1980, 2000, and 2015 urban extents; 1972, 1984, 1998, and 2015 road networks; land surface slope; hillshade image; and exclusion layer (Table 3). Urban coverages were extracted from the land cover maps that were developed and compiled in the previous section. For the road network, only primary roads were included and digitized from different sources (Landsat images, topographic maps (for the 1984 network), and Google Earth ${ }^{\circledR}$ (for the 2015 network)). In the exclusion layer, we obtained the map of the zoned area from GIM which shows the areas where development is permitted. These areas were given the value of 50 indicating neutrality, neither attracting nor preventing development, all other areas were given the value of 100 indicating the highest level of protection from development. A $30-\mathrm{m}$ resolution ASTER dataset was used to create inputs for slope and hillshade. All map inputs for slope, exclusion, urbanization, roads, and hillshade were converted to an 8-bit GIF format used by the SLEUTH-3r model (Figure 2). 
Table 3. SLEUTH inputs and variables.

\begin{tabular}{ll}
\hline Input & Data Source \\
\hline Slope, Hillshade & Derived from ASTER GDEM V2. Retrieved from: \\
Exclusion & https://earthexplorer.usgs.gov/ (accessed on 3 June 2017) \\
1972 Urban extent & Derived from GIM's zoning layer. \\
1980 s, 2000s, \& 2015s Urban extents & Derived from Landsat MSS scene. \\
1972 primary roads network & Derived from the JNLCD product. \\
1980 primary roads network & Derived from Landsat MSS scene. \\
2000 and 20,151 primary roads networks & Derived from high-resolution topographic map. Retrieved from: \\
\hline
\end{tabular}

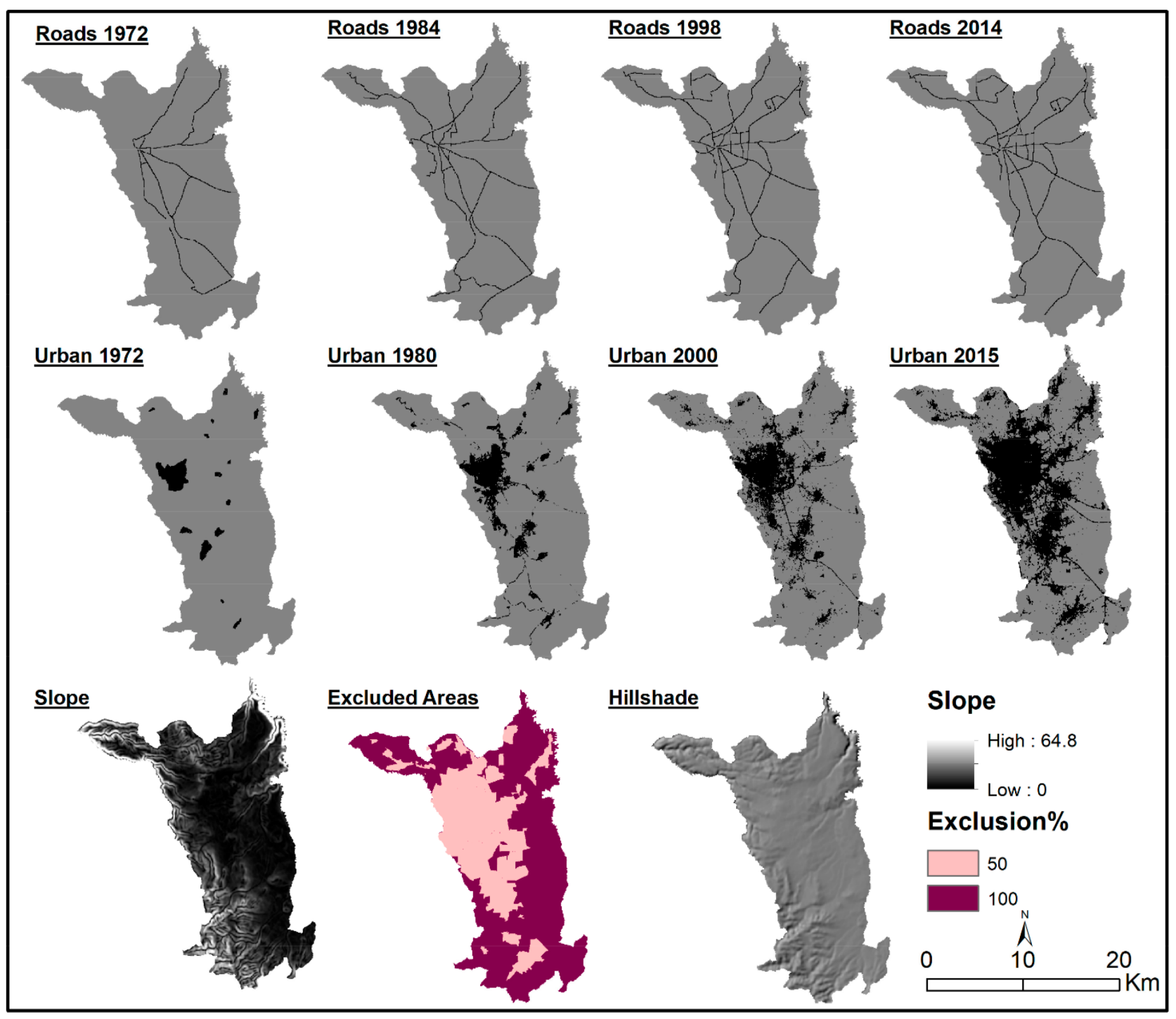

Figure 2. GIM inputs datasets to SLEUTH-3r.

The SLEUTH-3r calibration process is typically undertaken using a "brute force" methodology, in which many combinations of parameter values are tested automatically. In this process, both growth rules and self-modification rules are refined to the locale. The model has a "self-modification" function to simulate different rates of growth more realistically over time. When the urban growth rate exceeds a specified critical threshold, the growth coefficients are multiplied by a factor greater than one, simulating a development "boom" cycle. Similarly, when the urban growth rate falls below a specified critical 
threshold, the growth coefficients are multiplied by a factor less than one, simulating a development "bust" cycle. While the calibration process is usually performed in three phases; coarse, fine, and final, researchers proved negligible gains in performance among these phases.

Therefore, a coarse calibration in which all growth coefficient values ranged from 1 to 100 was performed with only increments of 25 were tested. The coarse calibration process for each study area was initiated to first set the appropriate Diffusion Multiplier value (DM) that can capture dispersive growth within GIM. In this process, the SLEUTH-3r's diffusion growth coefficients were set to produce the maximum level of dispersive growth (i.e., diffusion coefficient was set to 100 and all other growth coefficients set to 0 ). The proper DM value was when the cluster fractional difference first exceeded zero. The coarse calibration was then performed to develop growth coefficients for each area, including the four control years $(1972,1980,2000$, and 2015) and using all five growth coefficients with 25 Monte Carlo trials for each study (Figure 3).

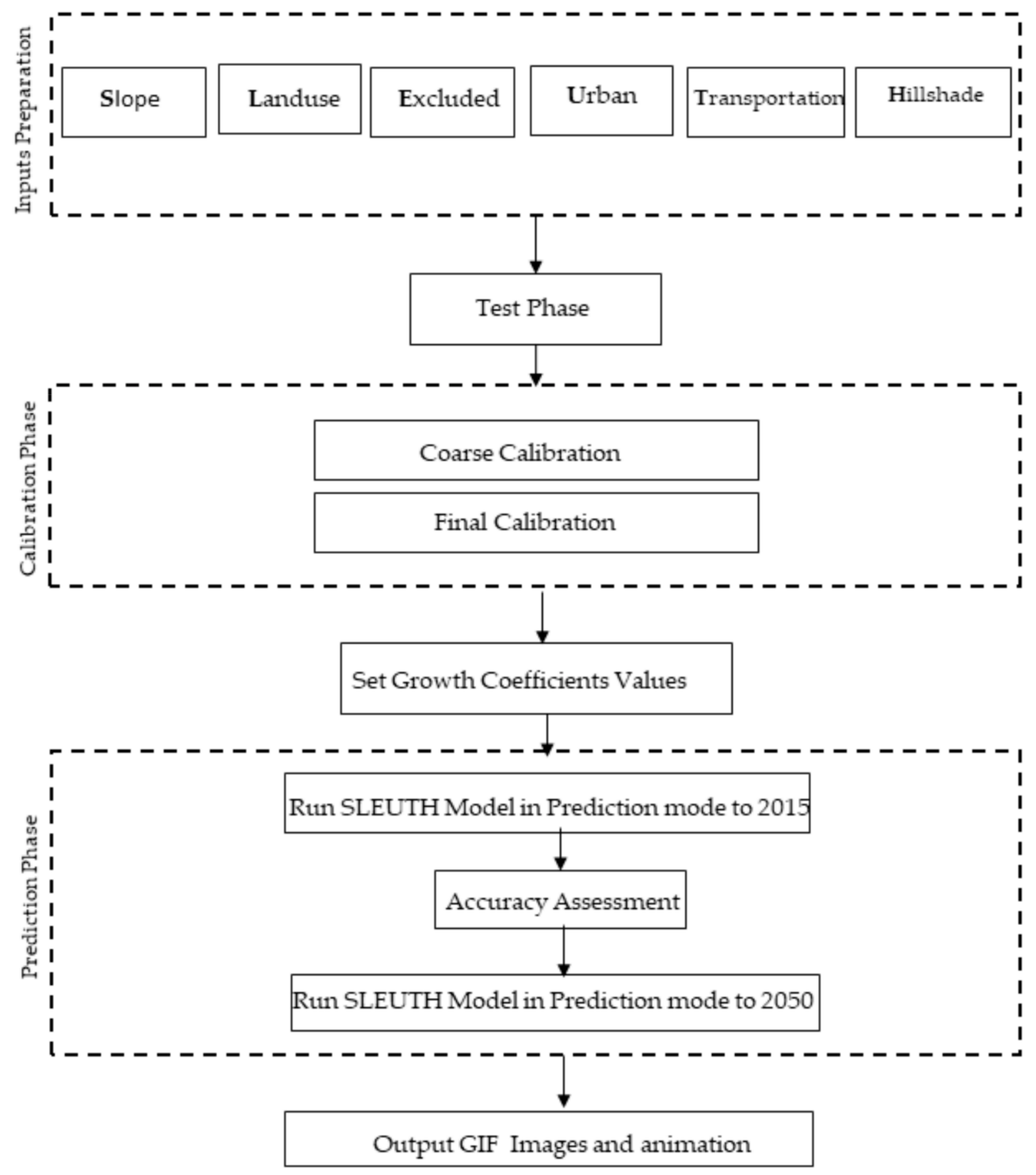

Figure 3. The flowchart of SLEUTH model.

To better evaluate the performance of the simulation phase and choose the appropriate growth coefficient values, representative goodness of fit measures was selected. Selecting proper fit statistics is crucial for an accurate future forecast; however, there is no agreement on a standard set. Here, the Pixel Fractional Difference PFD and Cluster Fractional Differ- 
ence CFD ratios were chosen because they proved to be the most relevant to the application of SLEUTH-3r. The metrics of Compare and Clusters were also chosen because they proved to provide the most robust results.

After the best-fit parameters were identified for the study areas, the model was initialized in 1972 and ran it in predict mode to 2015, with 25 Monte Carlo trials. This resulted in a predicted development probability surface for 2015, which I then compared to the observed patterns in 2015 to assess the accuracy of the calibration process.

\subsubsection{SLEUTH-3r Forecasts to 2050}

To create forecasts with SLEUTH, the model initially was run in prediction mode. The model was initialized with the latest urban extent map, the year 2015, and the growth coefficient values derived during the calibration phase. The target year was stopped in 2050 by performing 25 Monte Carlo trials using the same exclusion layer that was used for calibration. To evaluate the accuracy of the SLEUTH-3r forecast, a series of photos were taken in the years of 2015, 2017, and 2020 in three sites that showed a future infill development in SLEUTH predictions. These sites were in Idoon district which is one of the highly affected districts by urbanization in GIM.

\subsection{Land Cover Changes in GIM (1972-2050)}

For the 1972-2050 land cover change results, change trends and rates at the municipal and district levels were analyzed in two ways. (1) The areal coverages and change extents of land cover types were calculated for five periods of 1972-1980, 1980-1990, 1990-2000, 2000-2015, and 2015-2050 and (2) the proportions of built-up areas and agricultural land for the total area of each district were calculated for the years 1972, 2000, 2015, and 2050. The increased rate of urbanization and net change of agricultural land at the district level were calculated for the periods of 1990-2000, 2000-2015, and 2015-2050.

\section{Results}

\subsection{SLEUTH-3r Results}

The study found the DM value of 0.005 sufficient to capture dispersive growth around Irbid. The high score of the road gravity parameter demonstrates that historic urban growth in GIM was driven by a transportation network. Also, the high spread parameter reflected a high probability of urban growth outward the existing urban clusters. The final calibration correlations for compare_r ${ }^{2}$ and cluster_ $\mathrm{r}^{2}$ were high indicating that the model reflected the evolution of urbanization around Irbid. Comparison of the simulated urbanization against the actual urbanization of the control years reflected in the compared_score show that the model reflected the evolution of urbanization in the study area (a score of 0.98 ). The final calibration correlation was 0.84 in the case of the cluster_ $r^{2}$ (Table 4 ). The forecasted urban growth in GIM shows a continuation and intensification of development along transportation corridors (Amman-Irbid road and Petra road) to the south and east.

The accuracy assessment for the SLEUTH-3r predictions showed urban expansion (mostly infill development pattern) in three sites in Idoon district. The series of photos that were taken for each site in the years 2015, 2017, and 2020 proved the prediction results (Figure 4). The photos timeline reflects the present and most likely the future dominant housing type (residential multi-story buildings) in GIM offering tens of apartments in each building to meet the needs of the increasing urban dwellers. 
Table 4. Calibration accuracy results for Greater Irbid Municipality. The compare and cluster scores are given along 52 with the actual and simulated number of urban pixels, and the actual and simulated number of urban clusters for 53 2015. The best growth coefficients scores are out of 100.

\begin{tabular}{cc}
\hline Parameter/Growth Coefficient & Count/Score \\
\hline Compare $\mathbf{r}^{2}$ & 0.98 \\
Cluster r & 0.84 \\
2015 pixels & 109,880 \\
2015 simulated pixels & 108,030 \\
2015 clusters & 275 \\
2015 simulated clusters & 203 \\
Diffusion & $\mathbf{2 5}$ \\
Breed & $\mathbf{2 5}$ \\
Spread & $\mathbf{7 5}$ \\
Slope & $\mathbf{2 5}$ \\
Roads gravity & $\mathbf{7 5}$ \\
\hline
\end{tabular}
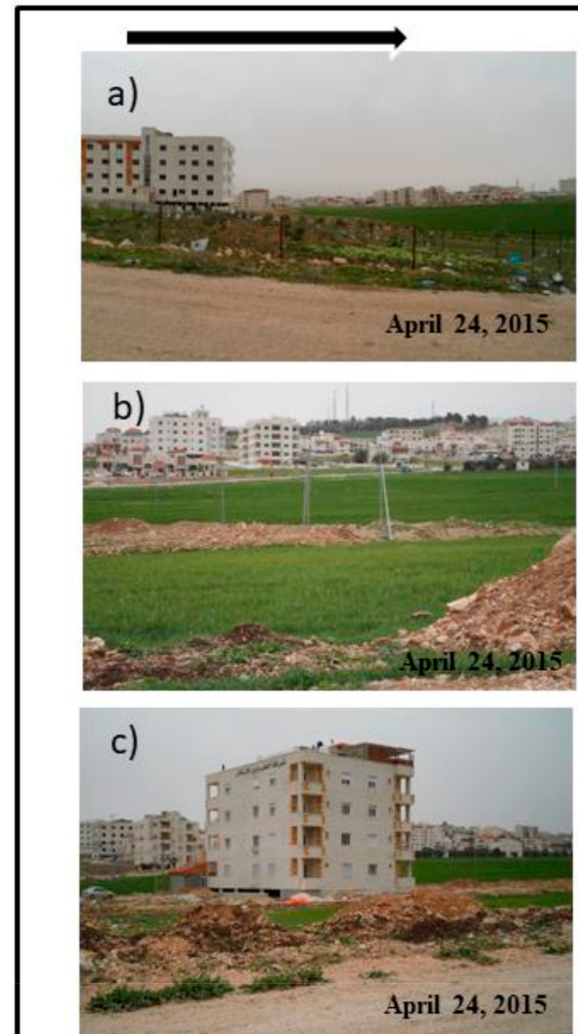
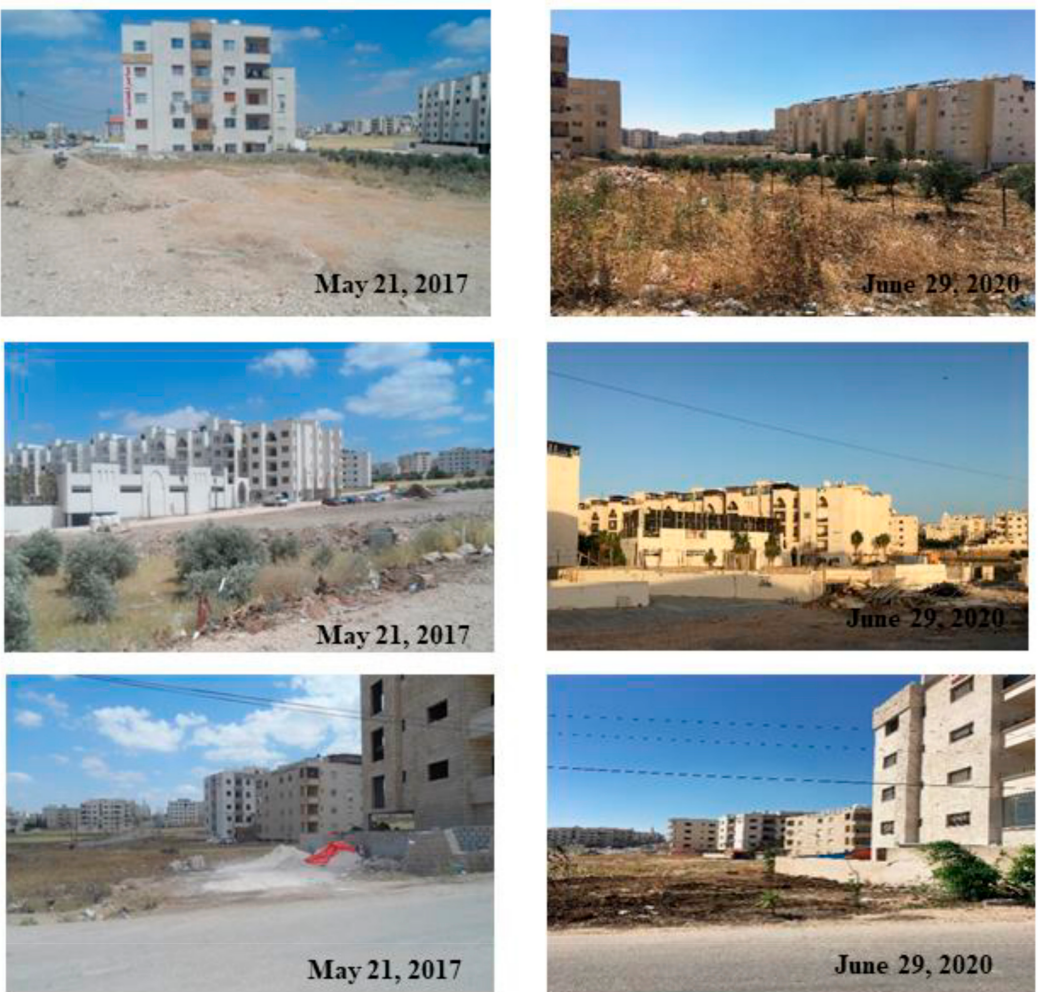

Figure 4. Timeline of photos for accuracy assessment of SLEUTH-3r projections in 3 sites located in Idoon from 2015-13 2020. These sites $(\mathbf{a}-\mathbf{c})$ are denoted in Figure 1. Photos taken by the author.

\subsection{Land Cover Change Analysis (1972-2050)}

\subsubsection{8-year Land Cover Dynamics in GIM}

Adding the newly created map (1972) to the JNLCDs (1980, 1990, 2000, and 2015) and the SLEUTH-3r forecasts to 2050 allowed for the development of a long-term land cover timeline for the second-largest populated city in Jordan (Figure 5). This timeline featured remarkable landscape transformation driven by significant urban growth across the 78 years. During the study period, Irbid City grew from a concentrated localized city surrounded by scattered low-intensity rural communities and vast primary cropland into a major metropolitan area in Jordan. 


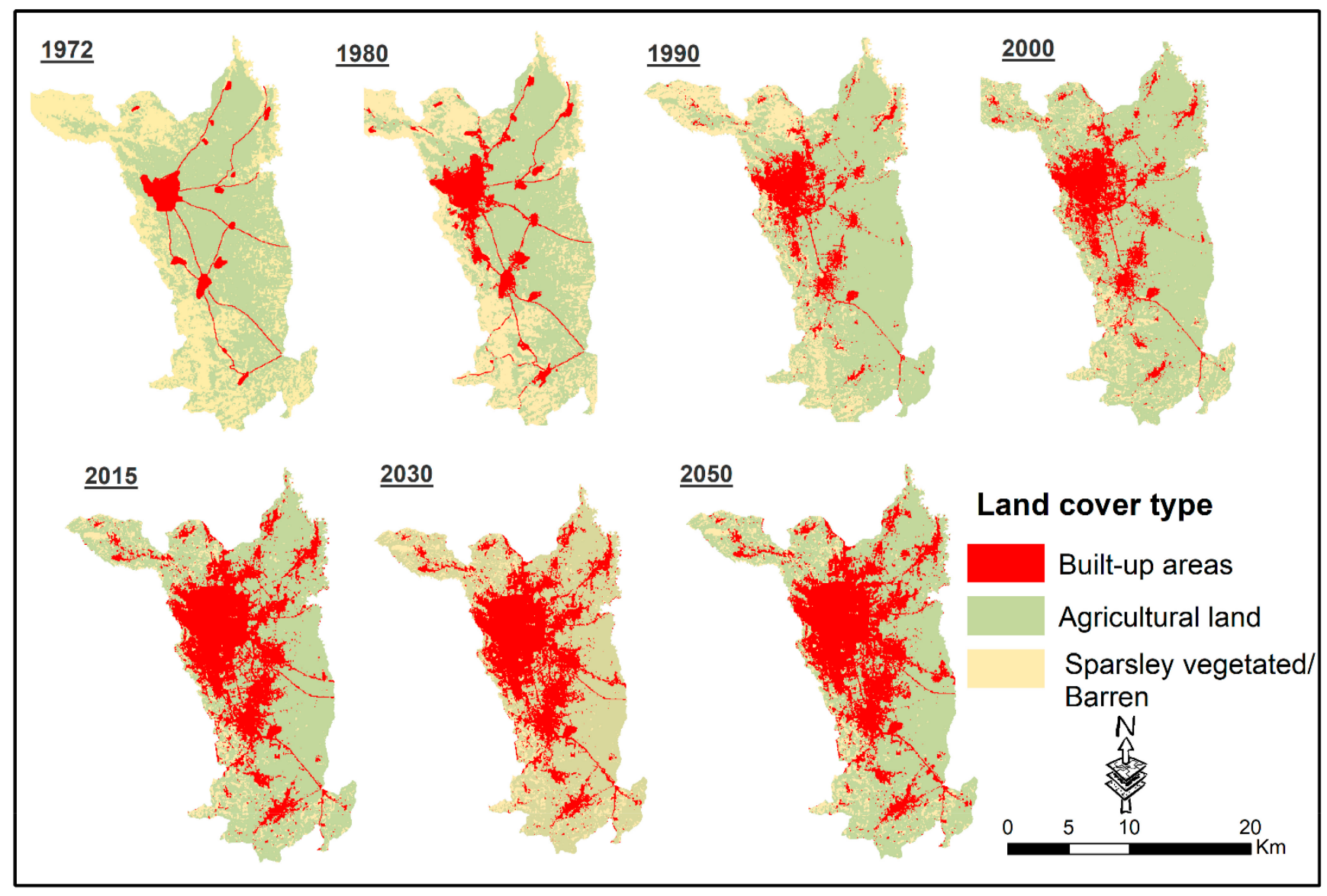

Figure 5. Long-term land cover timeline for the Greater Irbid Municipality (1972-2050).

Overall, built-up areas extent increased across the 78 years, with a total increase of $77.8 \mathrm{~km}^{2}$ or $72.7 \%$. (Table 5). According to the results during the mapping period, the total built-up areas coverage was $29.2 \mathrm{~km}^{2}$ (9\% of relative coverage) in 1972 and $100 \mathrm{~km}^{2}(31 \%$ of relative coverage) in 2015, and will likely increase to $107 \mathrm{~km}^{2}$ (33\% of relative coverage) by 2050 . Although persistently increasing, built-up areas change across the 78 years was not uniform in either space or time. Spatially, the southern and eastern parts of GIM area exhibited urban growth faster than the northern or western parts. Temporally, the rate of increase showed a decline across the study period, with the third and fourth intervals of 1990-2000 and 2000-2015 having the highest rate of built-up areas expansion at 68.6 and $41.4 \%$, respectively. However, the rate of increase will likely decline by 2050 at $6.6 \%$ reflecting the impacts of the economic and housing market recessions. 
Table 5. Land cover changes across the study period from 1972 to 2050, in $\mathrm{km}^{2}$.

\begin{tabular}{|c|c|c|c|c|c|c|c|c|c|c|c|c|c|}
\hline \multicolumn{2}{|l|}{1972} & \multicolumn{2}{|c|}{1980} & \multicolumn{2}{|c|}{1990} & \multicolumn{2}{|c|}{2000} & \multicolumn{2}{|c|}{2015} & \multicolumn{2}{|c|}{2050} & \multicolumn{2}{|c|}{ 1972-2050 } \\
\hline Land Cover & Area & $\begin{array}{l}\text { Change } \\
\text { 1972-1980 }\end{array}$ & Area & $\begin{array}{c}\text { Change } \\
\text { 1980-1990 }\end{array}$ & Area & $\begin{array}{c}\text { Change } \\
\text { 1990-2000 }\end{array}$ & Area & $\begin{array}{c}\text { Change } \\
2000-2015\end{array}$ & Area & $\begin{array}{l}\text { Change } \\
\text { 2015-2050 }\end{array}$ & Area & $\begin{array}{c}\% \text { of } 2050 \\
\text { Area }\end{array}$ & $\begin{array}{c}\text { 78-year } \\
\text { Change (\%) }\end{array}$ \\
\hline Built-up areas & 29.2 & 3.2 & 32.4 & 9.7 & 42.1 & 28.9 & 71 & 29.4 & 100.4 & 6.6 & 107 & 33 & $77.8(72.7 \%)$ \\
\hline Agricultural land & 178.2 & 3.2 & 181.4 & 19.5 & 200.9 & 6.1 & 207 & -12.4 & 194.6 & -6.6 & 188 & 58 & $\begin{array}{c}9.8 \\
(5.2 \%)\end{array}$ \\
\hline $\begin{array}{c}\text { Sparsely } \\
\text { vegetated/Barren }\end{array}$ & 116.6 & -6.6 & 110.2 & -29.2 & 81.0 & -36.0 & 45 & -16.0 & 29.0 & 0.0 & 29 & 9 & $\begin{array}{c}-87.6 \\
(-302 \%)\end{array}$ \\
\hline
\end{tabular}


The total 2015 GIM coverage of agricultural land was $194.6 \mathrm{~km}^{2}$ and will likely decline to $188 \mathrm{~km}^{2}$ by 2050. In 1972, the total extent of agricultural land was $178.2 \mathrm{~km}^{2}$ representing a slight $9.8 \mathrm{~km}^{2}$ expansion over 78 years. However, the rate of agricultural land change was not consistent across the fife intervals. The first three intervals of 1972-1980, 1980-1990, and 1990-2000 exhibited an increase in agriculture coverage, with the second interval of 1980-1990 having the highest rate of agricultural land increase at $10.7 \%$ (Table 5). The increase rate declined to 3\% for the following period of 1990-2000. Afterward, the total agriculture extent in GIM steadily declined, especially during the 2000-2015 period, with a total loss of $12.4 \mathrm{~km}^{2}$ at a decrease rate of $6 \%$. This loss of agricultural land will likely continue to the future at a slower rate of $3.4 \%$. The sparsely vegetated/barren coverage in GIM dramatically declined with a total loss of about $87.6 \mathrm{~km}^{2}$ (Table 5). According to the study results, the total sparsely vegetated/barre extent was $116.6 \mathrm{~km}^{2}$ in 1972 and $29 \mathrm{~km}^{2}$ in 2015. The highest rates of decline were notable during the third and fourth intervals of 1990-2000 and 2000-2015 with a change rate of -44.4 and $-35.6 \%$, respectively.

The results of land cover estimates for the year 2015 were compared against the estimates of the 2015 land cover map developed by Al-Kofahi et al. (2017) for GIM. The relative coverage of built-up areas in the 2015 JNLCD map was $30.8 \%$ while the urban space relative coverage in Al-Kofahi et al.'s map was $25 \%$. The relative coverages of agricultural land (green space) were $60 \%$ and $49 \%$ for the JNLCD and AL-Kofahi et al.'s maps, respectively. The extents of sparsely vegetated/barren (open space) were $9.2 \%$ and $26 \%$ for the JNLCD and Al-Kofahi et al.'s maps. The moderate differences in land cover estimates between the two maps can be attributed to the different mapping techniques used to derive land cover information in the two maps. The JNLCD product combined the unsupervised classification method with the rule-based classification to further designate the vegetated land cover types. The JNLCD classification method performed better $(89.7 \%$ overall accuracy) compared to Al-Kofahi et al.'s (80\% overall accuracy). Al-Kofahi et al.'s map was developed using a supervised classification method which proved to be less suitable when mapping a highly heterogeneous landscape as in GIM. Here, there could be many primary sources of confusion and disagreement such as confusion between open space and urban space, and between open space and agricultural land. For example, largescale queries are found in the study area which can be confused for urban spaces in the supervised classification due to the similarities in spectral reflectance. Also, a large number of small, fragmented family farms in the rigged up-land can be confused for open spaces.

\subsubsection{Urban Development Change at District Level (1972-2050)}

The previous analysis of land cover change in GIM showed a persistent and permanent urban increase in the study area over 78 years. However, the most urban change occurred after 1990 and was not spatially even across the study area. Therefore, urban change was examined at the district-level to identify where exactly and by how much urban development has transformed the landscape of GIM's districts in the past decades and will likely do in the next coming decades. Figure 6 illustrates proportions of built-up areas extend to the district area in 1972 (a) 2000 (b), 2015 (c), and 2050 (d). In general, districts within the main city limits (i.e., Hashmyah, Nozha, and Rawdah) and peripheral districts (i.e., Boshra, Idoon, and Bait Ras) exhibited larger proportions of built-up areas than the rural-dominant districts in the farthest north and south (i.e., $\mathrm{Al}^{\prime}$ al and $\mathrm{Nu}^{\prime}$ aymah). For example, the built-up area proportion in Hashmyah and Nozha districts increased from $75 \%$ and $6 \%$ in 1972 , respectively, to $100 \%$ in 2000 . To the east, the peripheral districts of Idoon and Boshra exhibited a substantial built-up expansion with proportion increased respectively from $0.6 \%$ and $0.9 \%$ in 1972 to $15 \%$ and $14.4 \%$ in 2000 , and to $53.1 \%$ and $48.9 \%$ in 2015. By 2050, the built-up proportion will likely increase to $56.9 \%$ in Idoon and to $55.6 \%$ in Boshra. 

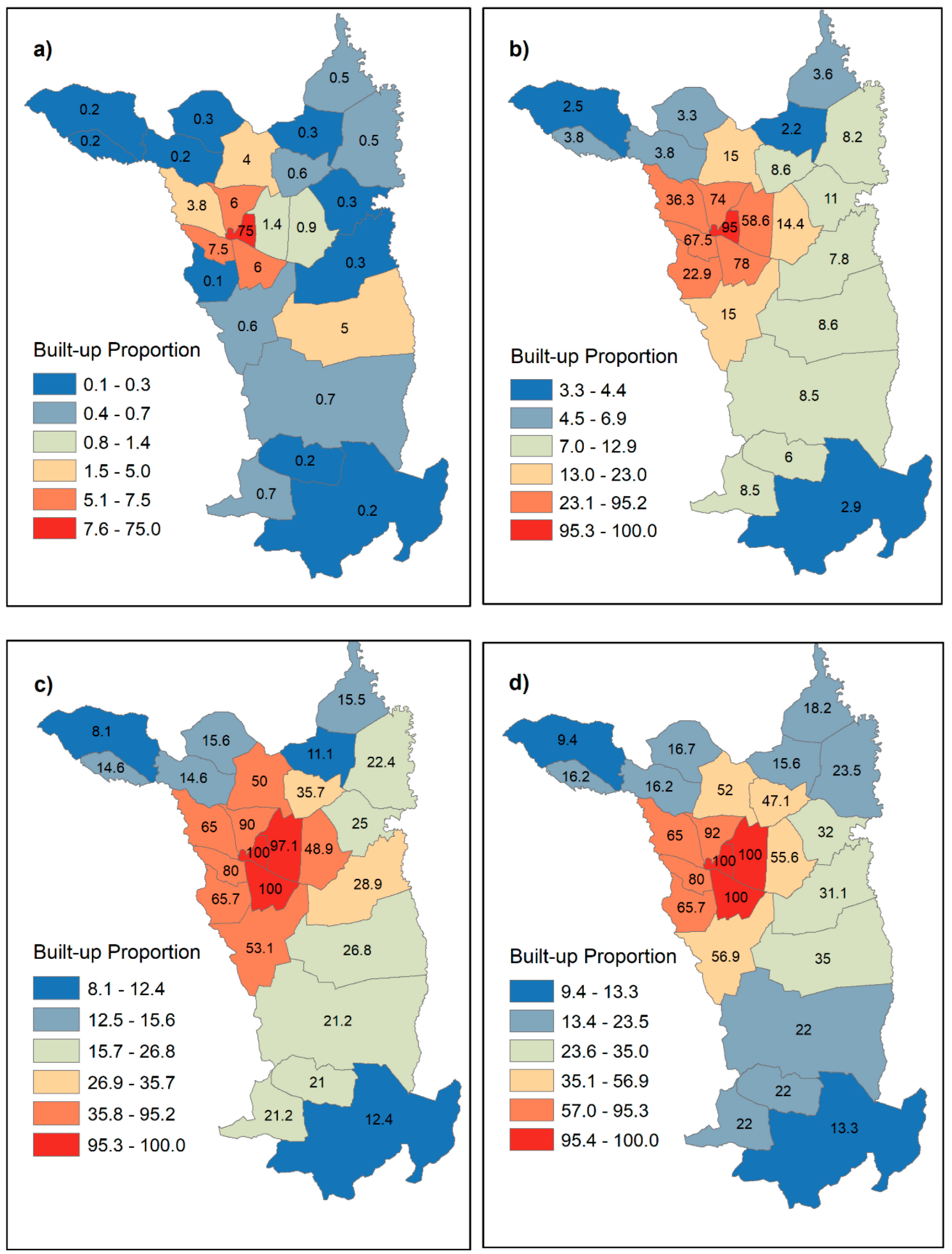

Figure 6. Proportions of built-up area for the total area of each district in 1972 (a), 2000 (b), 2015 (c), and 2050 (d).

Figure 7 shows the change rate of built-up areas extent from 1990-2000 (a), 2000-2015 (b), and 2015-2050 (c) in every district, with all districts exhibiting urban expansion from 19902000. During the 2000-2015 period, urban expansion continued in all districts, except for Hashmyah district as its land was completely developed. From 2000-2015 the majority of districts exhibited an urban increase at twice the rate of 1990-2000. No urban expansion is expected in five districts (Hashmyah, Nozha, Al-Barha, Al-Manarah, and Al-Rabiah) (Figure 7c) from 2015 to 2050, mainly because their lands would be completely developed. 
In the other 18 districts, however, urban increase rates are expected to decline. This declining rate has been denoted globally and can be attributed to the global recession, especially during and following the current COVID-19 pandemic.

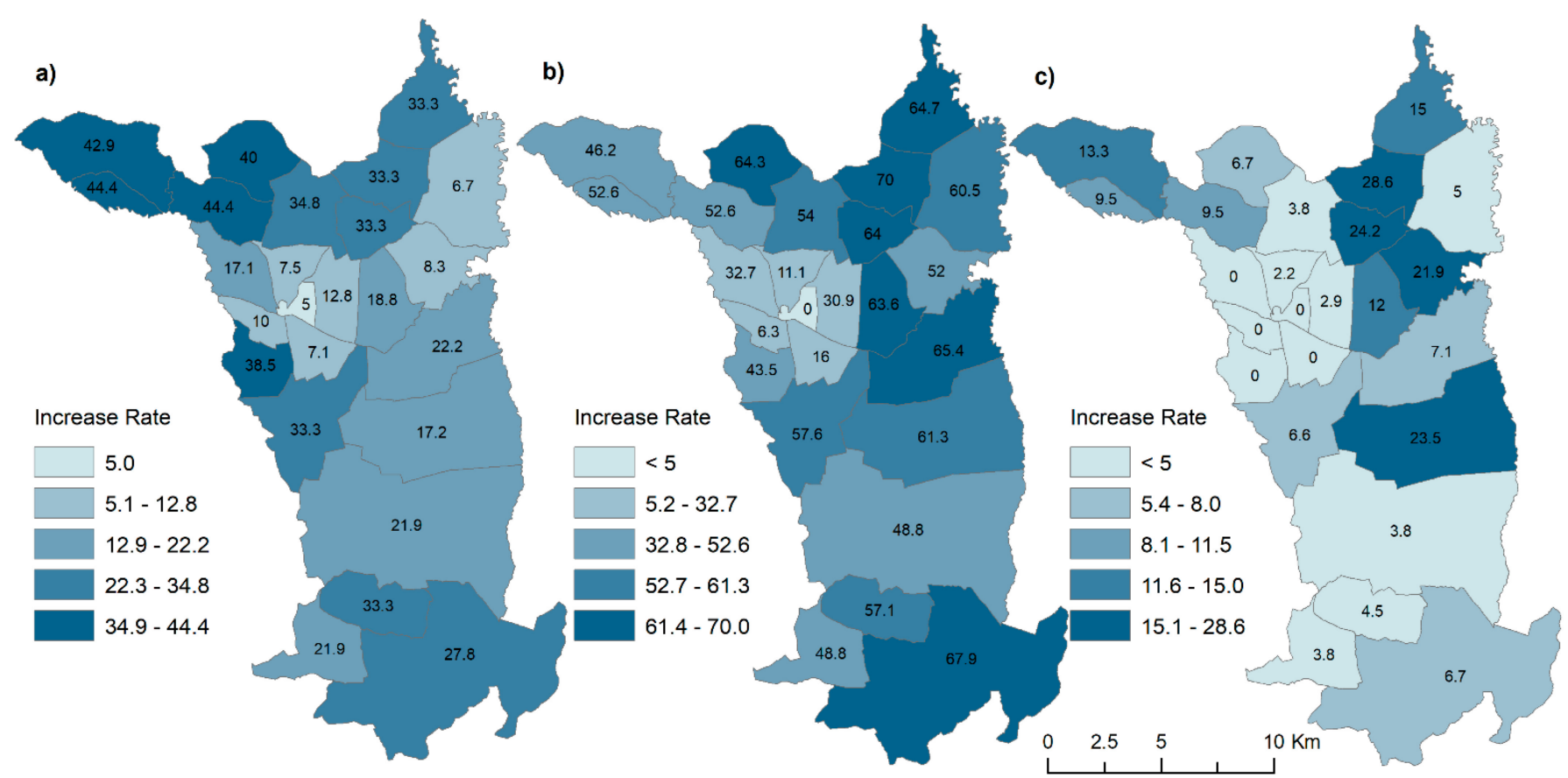

Figure 7. Built-up areas increase rate for each district between 1990-2000 (a), 2000-2015 (b), and 2015-2050 (c).

\subsubsection{Agriculture Change at District Level (1972-2050)}

Although the LULCC analysis at the GIM level time-spanning 78 years revealed an overall slight increase of land in agriculture, the rate of increase dramatically declined after 2000. The district-level analysis of proportions of agriculture extent to the district area shows that proportions of land in agriculture increased significantly from 1972 (Figure 8a) to 2000 (Figure 8b) in all districts except in Hashmyah. The ratios were greatest in the rural-dominant districts beyond the urban periphery (i.e., Ala'al, Hawar, Kafer Jayez). Conversely, all districts exhibited a decline in agriculture extent in 2015 (Figure 8c), with complete loss of agriculture share in the main city districts of Hashmyah, Nozha, and Rawdah. This decline in agriculture proportions will most likely continue to 2050, reflecting a slowdown in agricultural land consumption mainly by urbanization.

Figure 9 illustrates the net change in total agricultural land in a district for the intervals of 1990-2000, 2000-2015, and 2015-2050 expressed as a percentage of the total agricultural land in the base year $(1990,2000$, and 2015) of each interval. The results of the net change analysis of agriculture show that between 1990 and 2000, 9 districts exhibited a positive gain in agricultural land, with the districts of Kafer Jayez, Fo'ara, and Hawar having the highest gain rate at $54.5 \%, 51 \%$, and $36 \%$, respectively. The rest of the districts showed a negative loss of agricultural land, with the districts of Naser, Nozha, and Rawdah exhibiting the highest negative loss at 80\%, 36\%, and 35, respectively. From 2000 through 2015, the four districts of Naser, Nozha, Rawdah, and Hashmyah completely lost their agricultural areas for urbanization. The agricultural land consumption by urban growth expanded towards the peripheral districts, with Idoon having the highest negative loss of agricultural land at $51.5 \%$. From 2015 to 2050, no change in agricultural land expected in the districts within the main city limits due to either a complete consumption of agricultural land as the case in Nozha, Naser, Hashmyah, and Rawdah or to the topographic constraints of urban development as the case in Barha, Manarah, and Rabiah districts. The negative loss of land in agriculture will likely continue in all districts, with Hakama having the highest negative loss at $21 \%$ followed by Boshra at $13.6 \%$ and Sareeh and Idoon both at $11 \%$ 

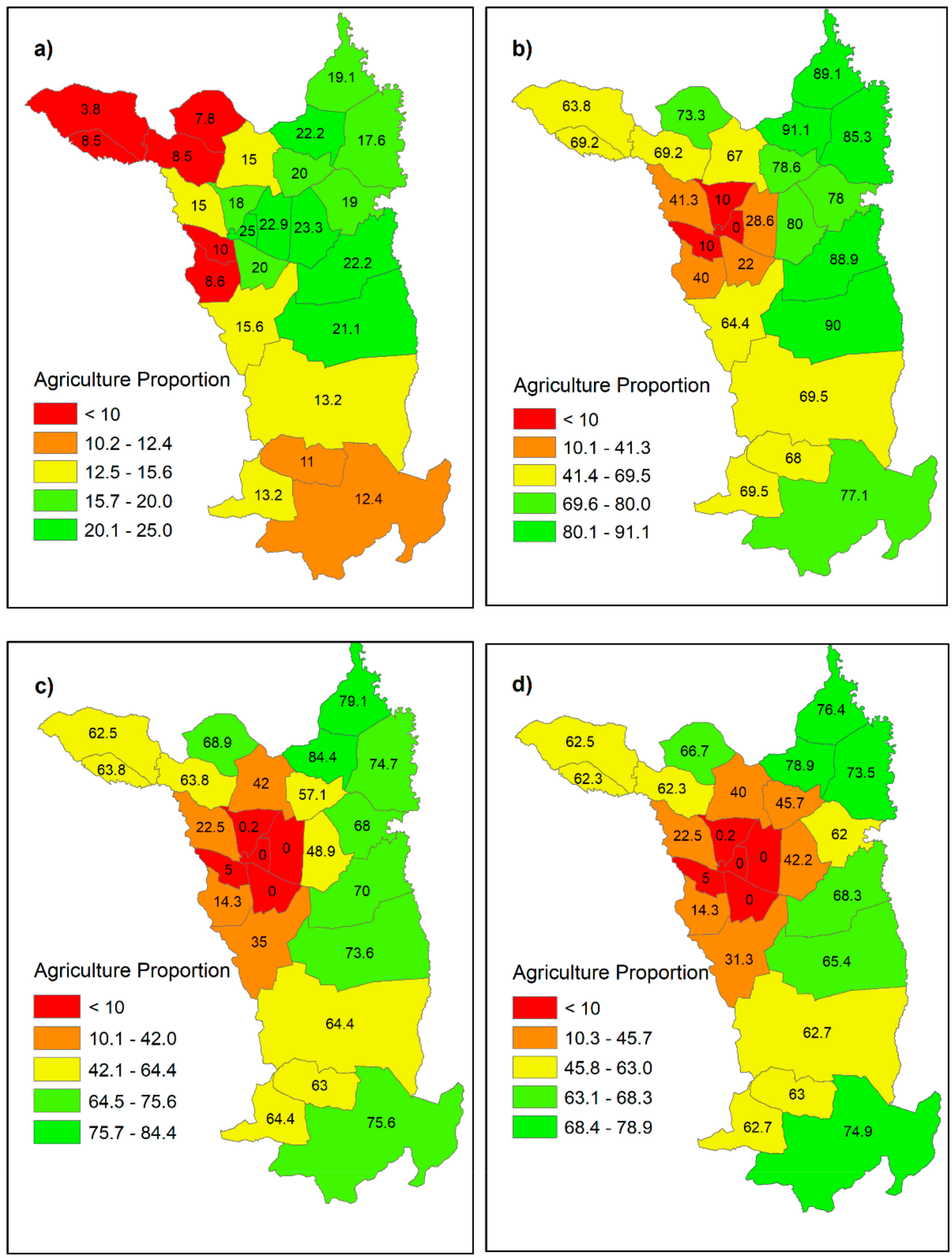

Figure 8. Proportions of agricultural land for the total area of each district in 1972 (a), 2000 (b), 2015 (c), and 2050 (d). 


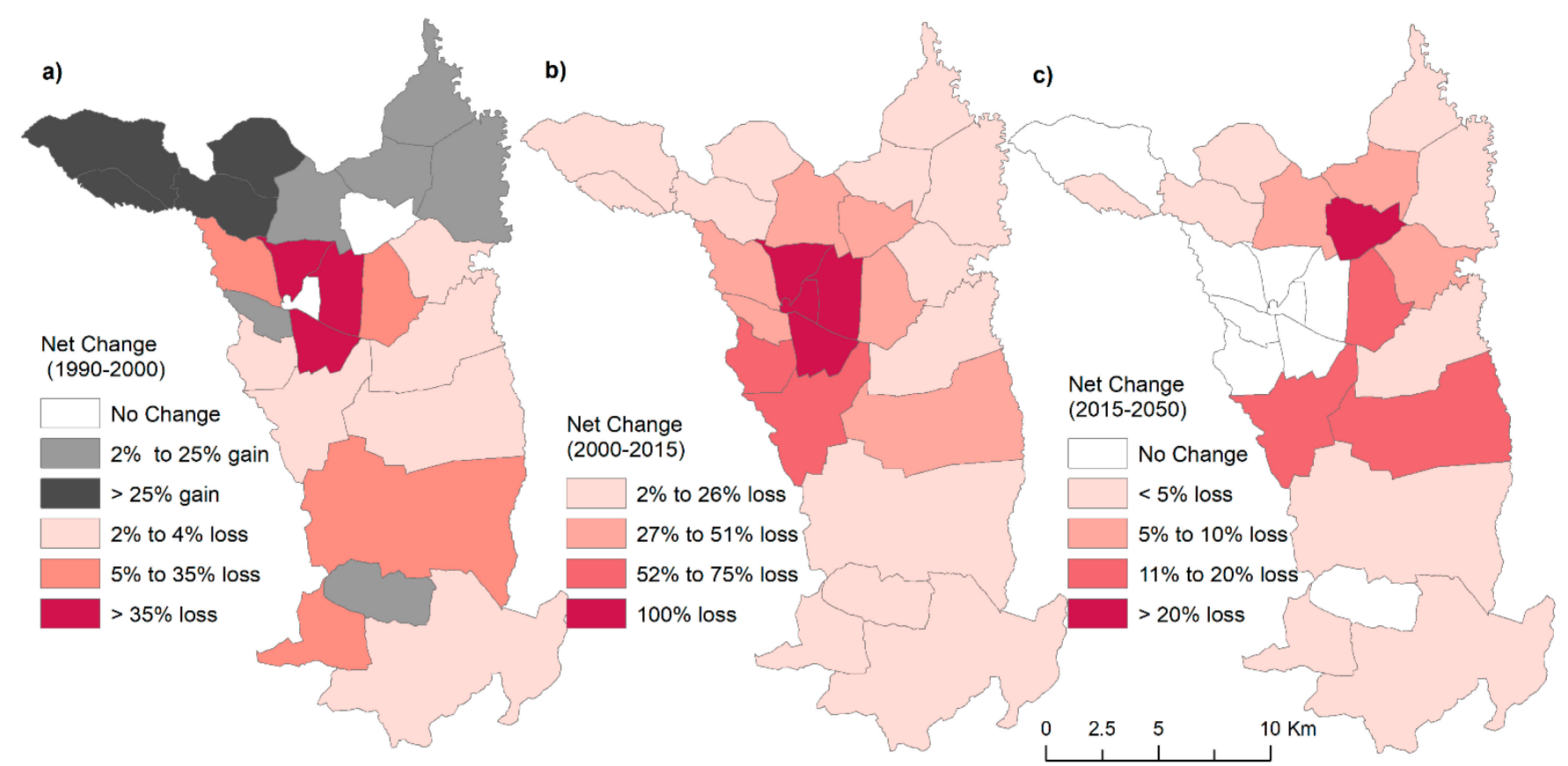

Figure 9. Net change in agricultural land in a district for the periods of 1990-2000 (a), 2000-2015 (b), and 2015-2050 (c).

\section{Discussion}

The previously presented results provide vital insights on the magnitude of land cover transformation and rate of agricultural land loss not only to Greater Irbid Municipality officials but also to Jordan Ministries of Environment, Agriculture, and local administration officials. These results question the efficiency and sustainability of decision-making in Jordan to ensure land resources and food security meanwhile introducing a new means of economic development crossing multiple aspects of an anthropogenic environment to help reach the 2030 UN Sustainable Development Goals (SDGs). Transitions towards adopting sustainable development models in decision-making can be challenging to a developing country such as Jordan. However, the movement should start immediately to demonstrate the commitment towards global eradicating poverty and achieving sustainable development by 2030. This study provides spatial evidence on past and future land transitions that can be of great value to local and national decision-makers to draw more sustainable planning policies based on realistic LULCCs.

\subsection{Agriculture Implications on Food and Food Security}

The LULC forecasts revealed that agricultural land will be the cover type that will suffer under urban expansion. The recession in agricultural land, as a response to urbanization, has been a worldwide problem hindering sustainable development strategies $[68,69]$. Generally, agricultural land that is adjacent to main urban areas mostly affected by irreversible urbanization. Such permanent replacement of agricultural land has negative consequences on arable lands and hence food production and food security. According to World Bank data, Jordan's arable land declined from 3.4\% to 2.6\% in 2015 [68]. Besides, arable land per person declined from 0.1 ha/cap in 1980 to 0.0 in 2015 . The negative consequences of the paradoxical competition between land for settlement and agricultural land for food. Such juxtaposition becomes more problematic when occurring in a limited resources country with agricultural land only accounts for $12 \%$ of its total areas [69]. Despite this steady decline of land in agriculture, the production increased in absolute terms. The absolute growth in agricultural products is mainly for cash export crops such as olives and fruit. In the late 1980s, Jordan's main agricultural development strategies were directed towards maximizing the production of irrigated agricultural lands in the Jordan River Valley and the arid region. Although between 1975 and 1980s cereal production 
reached a striking peak with an increased rate of $150 \%$, current and future production are expected to remain way far from meeting the domestic needs due to the highly fluctuated production from year-to-year resulting from frequent drought [70] and increasing agriculture abandonment [71-73].

Moreover, prices of food continue to rise globally; the FAO Food Price Index (FFPI) increased 2.1 points in August 2020 higher than its level in the same month in 2019 [72]. A reduction in cereal crop yields and wheat production is expected worldwide, with the current COVID-19 pandemic harshly affecting the top 50 food-exporting countries [72]. Although statistics showed that Jordan's agricultural output significantly rose from 2011 to 2016, with 2015 exhibiting the highest growth rate at 16\% [73], Jordan continues to be a food-importing country, with $98 \%$ of primary food products (i.e., grains) are imported [74]. Besides, nearly $3 \%$ of Jordanian households are food insecure and $53 \%$ are vulnerable to food insecurity [74]. This alarming situation of Jordan's agricultural sector and food security crisis requires urgent actions to preserve the available agricultural land from uncontrolled urban growth and to enhance households' resilience and food security by (1) incorporating geospatial technologies to simulate past and forecast future LULCC trajectories and their potential impact on the agricultural sector, and (2) providing financial and governmental support for farmers in governorates with high-quality agricultural land (i.e., Irbid governorate).

The SLEUTH simulation results allow for a thorough investigation on the foreseen status of agriculture given a case study from the most fertile agricultural plains in Jordan. The recession of rain-fed cropland in GIM confirms the observed trend not only in Jordan but in the MENA region as well, with an anticipated decline in agricultural production by $21 \%$ at the end of the 21st century [75] The forecasts presented in this research were based on assumption that reflects the "business as usual (BAU)" scenario indicating no change in the exclusion layer (only included land open for urban development). Nevertheless, the results reflect reality offering a vital baseline to evaluate other alternative scenarios in GIM and other areas in Jordan. Incorporating multiple socioeconomic and environmental variables in the exclusion layer of SLEUTH-3r along with the use of self-modifications of growth rates proved to be promising in simulating future trends under different scenarios $[28,67]$.

\subsection{Implications for Urban Planning in GIM}

Urban growth forecasts presented in this study assure the worldwide megatrend of urbanization and growth of metropolitan areas due to accelerating urban population growth [4]. The forecasted urbanization also aligns with the global urban sprawl pattern on the rural-urban fringe. The continued urban growth pattern in GIM is characterized by a low-density suburban growth (Figure 10a), with new urban cores. This urban growth can be attributed to multiple municipal, socioeconomic, demographic, and political variables that played a major role in increasing the urban population of GIM, especially after 2000 [59]. The number of populations, here, increased from 370,998 in 2000 to 535,199 in 2015 and expected to reach $1,219,055$ by 2050 [65]. As a result, housing demand and supply greatly increased to meet the needs for housing for the new urban dwellers. Such housing demand was triggered by an increase in the average annual income of households which, according to the Household Expenditure and Income Surveys, nearly tripled from 1,703 JOD in 1992 to 3,995 JOD in 2013, respectively. Statistics showed that the percentage of apartment units in Irbid increased from 51\% in 2006 to $64.7 \%$ in 2013, and 74.4\% in 2018 [76]. This may explain the widespread growth in multi-story residential buildings and the construction of new roads in the suburbs (Figures 4 and 10). The nationwide increase in housing units proved the ability of the housing sector to respond to the accelerating urban growth, especially after the influx of Iraqi and Syrian refugees. It was estimated that between 2004 and 2015, 1.1 million new units were built, exceeding the projected units $(300,000)$ by 800,000 units, contributing to an average of 7.2\% of GDP [77]. After 2015, nevertheless, the housing sector and real estate market, in general, collapsed because of many global economic shocks (i.e., 
Iraqi War, 2008 financial crisis, and Syrian conflict) [77,78]. A substantial slowdown in Jordan's GDP growth occurred and consequently resulted in a decline in urban growth.
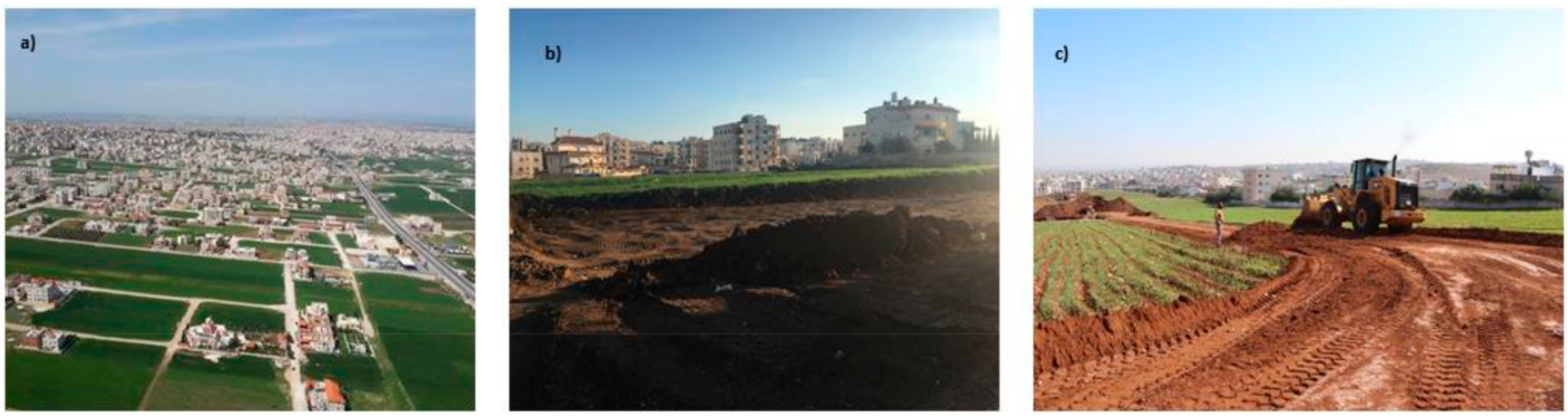

Figure 10. (a) Bird's view image of the southern side of GIM showing leapfrogging pattern in GIM area (photo taken in 27 2017; courtesy of pilot Mohammad Al-Zoubi; (b) Preparation for constructing a Multi-housing unit on the fertile red soil 28 in Idoon (photo taken by the author in April 2017); (c) New road construction through cultivated land in Hoson (Photo 29 taken on 18 November 2020; courtesy of Greater Irbid Municipality).

The forecasted results from 2015 to 2050 confirm this slowdown as the urban growth rate drastically decreased from $41.1 \%$ between 2000 and 2015 to only $6.6 \%$ between 2015 and 2050. The projected built-up areas will reach $107 \mathrm{~km}^{2}$ by 2050 -or $12 \mathrm{~km}^{2}$ below the officially zoned areas for urban development. This indicates that the available land for urban development is much more than what is needed and can accommodate future population growth of GIM beyond the year 2050 with no new land is consumed. With that said, however, the problem is that sufficient land might not be the right type for housing (i.e., agricultural land as the case in GIM), causing a structural shortage and mismatch between the types of residential land available on the market and the actual types needed. This structural shortage has led to reduce the land available for affordable housing and consequently increase the cost per housing unit [77]. This dilemma of shortage in land available for affordable housing might be driven by the inappropriate zoning categories of residential areas (A for luxurious housing, B for low-density higher-end housing, C and D for higher-density more affordable housing). Since the amalgamation process in 2001, new areas in GIM have been added for housing yet mostly zoned for the higher-end housing (Zones A and B) with large plot size and hence the least affordable type for housing. Besides the structural shortage of land available for development, land zoning in Irbid represents a mixture of urban and rural land uses with an absence of environmental, political, and social planning. City planning policies, generally, are drawn in favor of a group of competitors and upon expectations rather than demographic and socioeconomic statistics.

\section{Conclusions}

This study investigated past, present, and future land cover transformations at both the municipality and district levels of Greater Irbid Municipality featuring the application of SLEUTH for the first time in Jordan. The magnitude of past land cover changes and the foreseen changes were examined. The findings of this research suggest that GIM landscape composition exhibited a significant change in the past decades and will continue to experience more changes mainly associated with urbanization. The amount of agricultural land lost for urban development is of great value for sustainable development. Both fragmentations of agricultural lands and urbanization have been recognized as the main challenges in sustaining and developing the agricultural sector in Irbid. GIM is in urgent need of the adoption of a compact policy by which no more new lands are added for urban development. Infill development patterns should be enforced, and the striking land prices should be regulated.

While past urban growth in GIM was mainly driven by changing lifestyles and ruralurban migration, present growth is highly driven by the influx of refugees from neighboring 
countries, changing municipal policies, and socioeconomic transformations. The present and future low-intensity growth patterns are shaped by arbitrarily urban planning policies, absence of an environmental land value, land speculation, and striking land prices. GIM suffers from uncontrolled land uses as there are no hierarchy of zones and most areas are mixed-uses. Irbid city is unique in its location, physiographic settings, and agricultural value. Yet, urban planning strategies did not preserve this value and its environmental assets. Urban planning strategies must be drawn within a more sustainable development model reflecting an official commitment to attaining the SDGs goals and targets towards achieving "sustainable urbanization and capacity for participatory, integrated and sustainable human settlement planning and management in all countries" (SDG 11 (11.3)). City municipal boundaries should have been adjusted at several stages over time and based on reliable demographic and socioeconomic variables. For a balanced development, municipal authorities need tools to monitor how the land is currently used, assess future demand, and take actions to assure adequacy of future supply. This research promotes and supports sustainable development planning through producing spatially explicit forecasts proving the efficiency and capability of forecasting to not only investigating the implications for agriculture, food security, and urban planning but also to use the results as input to other models to measure consequences on, for instance, land degradation and water quality. Such information is of great importance for decision-making in Jordan where there is an urgent need for proper land management practices and sustainable land-use policies.

Funding: This research received no external funding.

Institutional Review Board Statement: Not Applicable.

Informed Consent Statement: Not Applicable.

Data Availability Statement: Not Applicable.

Conflicts of Interest: The author declares no conflict of interest.

\section{References}

1. Del Mar López, T.; Aide, T.M.; Thomlinson, J.R. Urban expansion, and the loss of prime agricultural lands in Puerto Rico. Ambio J. Hum. Environ. 2001, 30, 49-54. [CrossRef]

2. Pribadi, D.; Pauleit, S. The dynamics of peri-urban agriculture during rapid urbanization of Jabodetabek Metropolitan Area. Land Use Policy 2005, 48, 13-24. [CrossRef]

3. Shi, K.; Chen, Y.; Yu, B.; Xu, T.; Li, L.; Huang, C.; Liu, R.; Chen, Z.; Wu, J. Urban expansion and agricultural land loss in China: A multiscale perspective. Sustainability 2016, 8, 790. [CrossRef]

4. United Nations, Department of Economics and Social Affairs, Population Division. World Urbanization Prospects: The 2014 Revision (ST/ESA/SER.A/352); United Nations: New York, NY, USA, 2014. Available online: https://esa.un.org/unpd/wup/publications/ files/wup2014-highlights.Pdf (accessed on 26 December 2020).

5. Foley, J.; DeFries, R.; Asner, G.; Barford, C.; Bonan, G.; Carpenter, S.; Chapin, F.; Coe, M.; Daily, G.; Gibbs, H.; et al. Global consequences of land use. Science 2005, 309, 570-574. [CrossRef] [PubMed]

6. Lambin, E.F.; Geist, J.; Lepers, E. Dynamic of land-use and land-cover in tropical regions. Annu. Rev. Environ. Resour. 2003, 28, 205-241. [CrossRef]

7. Seto, K.; Güneralp, B.; Hutyra, L. Global Forecasts of urban expansion to 2030 and direct impacts on biodiversity and carbon pools. Proc. Natl. Acad. Sci. USA 2012, 109, 16083-16088. [CrossRef] [PubMed]

8. Sudhira, H.; Ramachandra, T.; Jagadish, K. Urban Sprawl: Metrics, dynamics and modelling using GIS. Int. J. Appl. Earth Obs. Geo-Inf. 2004, 5, 29-39. [CrossRef]

9. Holcombe, R.; Williams, D. Urban sprawl and transportation externalities. Rev. Reg. Stud. 2010, 40, $257-273$.

10. Hamidi, S.; Ewing, R. A longitudinal study of changes in urban sprawl between 2000 and 2010 in the United States. Landsc. Urban. Plan. 2014, 128, 72-82. [CrossRef]

11. Hart, J. The perimetropolitan Bow wave. Geogr. Rev. 1991, 81, 35-51. [CrossRef]

12. Jawarneh, N.; Julian, J.; Lookingbill, T. The influence of physiography on historical and future land development changes: A case study of central Arkansas (USA), 1857-2030. Landsc. Urban. Plan. 2015, 143, 76-89. [CrossRef]

13. Lavy, B.; Julian, J.; Jawarneh, N. The Impact of past and future urban expansion on soil resources in central Arkansas, 1994-2030. Pap. Appl. Geogr. 2016, 2, 25-39. [CrossRef]

14. Yu, X.; $\mathrm{Ng}, \mathrm{C}$. Spatial and temporal dynamics of urban sprawl along two urban-rural transects: A case study of Guangzhou, China. Landsc. Urban. Plan. 2007, 79, 96-109. [CrossRef] 
15. Lu, D.; Tian, H.; Zhou, G.; Ge, H. Regional mapping of human settlements in southeastern China with multi sensor remotely sensed data. Remote Sens. Environ. 2008, 112, 3668-3679. [CrossRef]

16. Bhatta, B. Analysis of urban growth pattern using remote sensing and GIS: A case study of Kolkata. Int. J. Remote Sens. 2009, 30, 4733-4746. [CrossRef]

17. Tv, R.; Aithal, B.; Sanna, D. Insights to urban dynamics through landscape spatial pattern analysis. Int. J. Appl. Earth Obs. Geo-Inf. 2012, 18, 329-343. [CrossRef]

18. Losiri, C.; Nagai, M.; Ninsawat, S.; Shrestha, R. Modeling urban expansion in Bankok metropolitan region using demographiceconomic data through cellular automata-Markov chain and multi-layer perceptron-Markov chain models. Sustainability 2016, 8 , 686. [CrossRef]

19. Yue, W.; Zhang, L.; Liu, Y. Measuring sprawl in large Chinese cities along the Yangtze River via combined single and multidimensional metrics. Habitat Int. 2016, 57, 43-52. [CrossRef]

20. Lizuka, K.; Johnson, B.; Onishi, A.; Magcale-Macandog, D.; Endo, I.; Bragais, M. Modeling future urban sprawl and landscape change in the Laguna de Bay Area, Philippines. Land 2017, 6, 1-21.

21. Cohen, B. Urban growth in developing countries: A review of current trends and a caution regarding existing forecasts. World Dev. 2004, 32, 23-51. [CrossRef]

22. Song, W.; Liu, M. Farmland conversion decreases regional and national land quality in China. Land Degrad. Dev. 2016, 28, 459-471. [CrossRef]

23. Ramankutty, N.; Foley, J.; Olejniczak, N. People on the land: Changes in global population and croplands during the 20th century. AMBIO J. Hum. Environ. 2002, 31, 251-257. [CrossRef]

24. Dietzel, C.; Clarke, K. Toward optimal calibration of the SLEUTH land use change model. Trans. GIS 2007, 11, 29-45. [CrossRef]

25. Garcia, A.; Sante, I.; Boullon, M.; Crecente, R. A Comparative anaylsis of cellular automata models for simulation of small urban areas in Galicia, NW Spain. Comput. Environ. Urban Syst. 2012, 36, 291-301. [CrossRef]

26. Oguz, H.; Klein, A.G.; Srinivasan, R. Using SLEUTH urban growth model to simulate the impacts of future policy scenarios on urban land use in the Houston-Galveston-Brazoria CMSA. Res. J. Soc. Sci. 2007, 2, 72-82.

27. Clarke, K.; Gaydos, L.; Hoppen, S. A self-modifying cellular automaton model of historical urbanization in the San Francisco Bay area. Environ. Plan. B 1997, 24, 247-261. [CrossRef]

28. Jantz, C.; Goetz, S.; Donato, D.; Claggett, P. Designing and implementing a regional urban modeling system using the SLEUTH cellular urban model. Comput. Environ. Urban Syst. 2010, 34, 1-16. [CrossRef]

29. Chaudhuri, G.; Clarke, K. The SLEUTH land use change model: A review. Int. J. Environ. Resour. Res. 2013, 1, 88-105.

30. Guan, Q.; Clarke, K. A general-purpose parallel raster processing programming library test application using a geographic cellular automata model. Int. J. Geogr. Inf. Sci. 2010, 24, 695-722. [CrossRef]

31. Clark, K. A decade of cellular urban modeling with SLEUTH: Unresolved issues and problems. In Planning Support Systems for Cities and Regions, 1st ed.; Brail, R., Ed.; The Lincoln Institute of Land Policy: Cambridge, MA, USA, 2008; pp. 47-60.

32. Yang, X.; Lo, C.P. Modeling urban growth and landscape change in the Atlanta metropolitan area. Int. J. Geogr. Inf. Sci. 2003, 17, 463-488. [CrossRef]

33. Silva, A.; Clarke, K. Calibration of the SLEUTH urban growth model for Lispon and Porto, Portugal. Comput. Environ. Urban Syst. 2002, 26, 525-552. [CrossRef]

34. Caglioni, M.; Pelizzoni, M.; Rabino, G. Urban sprawl: A case study for project Gigalopolis using SLEUTH model. Lect. Notes Comput. Sci. 2006, 4173, 436-445.

35. Martellozzo, F.; Amato, F.; Murgante, B.; Clarke, K. Modelling the impacts of urban growth on agriculture and natural land in Italy to 2030. Appl. Geogr. 2018, 91, 156-167. [CrossRef]

36. Rafiee, R.; Mahiny, A.; Khorasani, N.; Darvishefat, A.; Danekar, A. Simulating urban growth in Mashad City, Iran through the SLEUTH model (UGM). Cities 2009, 26, 19-26. [CrossRef]

37. Abd-Allah, M. Modelling Urban Dynamics Using Geographic Information Systems, Remote Sensing, and Urban Growth Models. Ph.D. Thesis, Cairo University, Cairo, Egypt, 2007.

38. Azaz, L. Monitoring, Modelling, and Managing Urban Growth in Alexandria, Egypt Using Remote Sensing and GIS. Ph.D. Thesis, The University of New Castle, New Castle upon Tyne, UK, 2004.

39. Al-Awadhi, T. Monitoring and modeling urban expansion using GIS \& RS: Case study from Muscat, Oman. In Proceedings of the IEEE 2007 Urban Remote Sensing Joint Event, Paris, France, 11-13 April 2007; pp. 1-5.

40. Al-Shalabi, M.; Billa, L.; Pradhan, B.; Mansor, S.; Sharif, A. Modeling urban growth evolution and land-use changes using GIS based cellular automata and SLEUTH models: The case of Sana'a metropolitan city, Yemen. Environ. Earth Sci. 2012, 70, 425-437. [CrossRef]

41. UN-FPA, United Nations Population Fund. State of the World Population 2007: Unleashing the Potential of Urban Growth 2007. Available online: https:/ / www.unfpa.org/sites/default/files/pub-pdf/695_filename_sowp2007_eng.pdf (accessed on 15 October 2020).

42. United Nations Human Settlements Programme (UN-Habitat). UN-Habitat Global Activities Report: Increasing Synergy for Greater National Ownership 2005. Available online: https://sustainabledevelopment.un.org/content/documents/1726Habitat\% 20Global\%20Activties\%202015.pdf (accessed on 2 January 2021). 
43. United Nations Economic and Social Commission for Western Asia (UN-ESCWA). (2019). Moving towards Water Security in the Arab Region 2019. Available online: https://www.unescwa.org/sites/www.unescwa.org/files/publications/files/movingtowards-achieving-water-security-arab-region-english.pdf (accessed on 11 December 2020).

44. Megahed, Y.; Cabral, P.; Silva, J.; Caetano, M. Land Cover mapping analysis and urban growth modeling using remote sensing techniques in Greater Cairo Region-Egypt. ISPRS Int. J. Geo-Inf. 2015, 4, 1750-1769. [CrossRef]

45. Esmail, M.; Masria, A.; Negm, A. Monitoring land use/land cover changes around Damietta Promontory, Egypt, using RS/GIS. Procedia Eng. 2016, 154, 936-942. [CrossRef]

46. Jawarneh, N.; Biradar, C. Decadal land cover database for Jordan at $30 \mathrm{~m}$ resolution. Arab. J. Geosci. 2017, 10, 483-496. [CrossRef]

47. Al-Kofahi, S.; Hammouri, N.; Sawalhah, M.; Al-Hammouri, A.; Aukour, F. Assessment of the urban sprawl on agricultural lands of two major municipalities in Jordan using supervised classification techniques. Arab. J. Geosci. 2018, 11, 45. [CrossRef]

48. Saleh, B.; Al Rawashdeh, S. Study of urban expansion in Jordanian cities using GIS and remote sensing. Intern. J. Appl. Sci. Eng. 2007, 5, 41-52.

49. Khresat, S.; Al-Bakri, J.; Tahhan, R. Impacts of land use/cover change on soil properties in the Mediterranean region of NorthWestern Jordan. Land Degrad. Dev. 2008, 18, 1-11. [CrossRef]

50. Al-Bakri, J.; Duqqah, M.; Brewer, T. Application of remote sensing and GIS for modeling and assessment of Land use/cover change in Amman/Jordan. Sci. Res. 2013, 5, 509-519. [CrossRef]

51. Hjorat, K.; Zakaria, M.; Salah, F. An Introduction to Jordan's Agriculture Sector and Agricultural Policies. USAID, Amman 1998 Available online: http:/ / www.fao.org/3/ba0007e/ba0007e.pdf (accessed on 18 January 2021).

52. Ministry of Planning and International Cooperation. 2017. Available online: http://inform.gov.jo/en-us/By-Date/ Report-Details / ArticleId/63/smid/420/ArticleCategory/216/Assessment-of-the-Agricultural-Sector-in-Jordan (accessed on 15 January 2021).

53. Al Rawashdeh, S.; Saleh, B. Satellite monitoring of urban spatial growth in the Amman area, Jordan. J. Urban Plan. Dev. 2006, 132, 211-216. [CrossRef]

54. Potter, R.; Darmame, K.; Barham, N.; Nortcliff, S. Ever-growing Amman, Jordan: Urban expansion, social polarisation and contemporary urban planning issues. Habitat Int. 2009, 33, 81-92. [CrossRef]

55. Makhadmeh, Z.; Almanasyeh, N. Analyzing the state and pattern of urban growth and city planning in Amman using satellite images and GIS. Eur. J. Soc. Sci. 2001, 24, 252-264.

56. Alnsour, J. Managing urban growth in the city of Amman, Jordan. Cities 2016, 50, 93-99. [CrossRef]

57. Ababsa, M. Municipalities and issue of local governance. In Atlas of Jordan: History, Territories and Society; Presses de l'Ifpo: Beirut, Lebanon, 2013; pp. 374-383.

58. Stave, S.; Hillesund, S. Impact of Syrian Refugees on the Jordanian Labour Market: Findings from the Governorates of Amman, Irbid and Mafraq; International Labour Office: Geneva, Switzerland, 2015; Available online: https://www.ilo.org/wcmsp5/groups/public/ ---arabstates/---ro-beirut/documents/publication/wcms_364162.pdf (accessed on 20 October 2020).

59. Al-Hashimi, I.; El-Azzawi, A.; El-Kasbi, H. Dynamics of urban growth: Modeling the fractal dimension of the city of Irbid, Jordan. Jordan J. Civ. Eng. 2013, 7, 1-16.

60. Tarrad, M. Urban planning response to population growth in Jordanian cities (Irbid city as case study). Res. J. Appl. Sci. Eng. Technol. 2014, 7, 4275-4280. [CrossRef]

61. Al-Kofahi, S.; Jamhawi, M.; Hajahjah, Z. Investigating the current status of geospatial data and urban growth indicators in Jordan and Irbid municipality: Implications for urban and environmental planning. Environ. Dev. Sustain. 2017, 20, 1067-1083. [CrossRef]

62. Sharieh, A.; Barham, R.; Jaradat, S. Urban sprawl impact on agricultural lands in Irbid City, Jordan. J. Environ. Earth Sci. 2017, 7, 107-118.

63. Tarawneh, M.; Naamneh, M. Urbanization and social identities in Jordan: The case of Irbid. J. Comp. Fam. Stud. 2011, 42, 615-635. [CrossRef]

64. Al-Qudah, B. Soils of Jordan. In Soil Resources of Southern and Eastern Mediterranean Countries; Zdruli, P., Steduto, P., Montanarella, L., Eds.; CIHEAM/Istituto Agronomico Mediterraneo di Bari (IAMB): Bari, Italy, 2001; pp. 127-141.

65. Department of Statistics (DoS). Population Projections for the Kingdom's Residents during the Period 2015-2050. 2019. Available online: http:/ / www.dos.gov.jo/dos_home_e/main/Demograghy /2017/POP_PROJECTIONS(2015--2050).pdf (accessed on 20 November 2019).

66. Al-Huseini, J. The evolution of the Palestinian refugee camps in Jordan. between logics of exclusion and integration. In Cities, Urban Practices and Nation Building in Jordan; Ababsa, M., Daher, R., Eds.; Presses de L'lfpo: Beirut, Lebanon, 2011 ; pp. 181-204.

67. Homer, C.; Dewitz, J.; Jin, S.; Xian, G.; Costello, C.; Danielson, P.; Gass, L.; Funk, M.; Wickham, J.; Stehman, S.; et al. Conterminous United States land cover change patterns 2001-2016 from the 2016 National Land Cover Database. ISPRS J. Photogramm. Remote Sens. 2020, 162, 184-199. [CrossRef]

68. World Bank. World Development indicators. Available online: https://databank.worldbank.org/source/world-developmentindicators (accessed on 8 March 2021).

69. Food and Agriculture Organization of the United States. Country Profile. Available online: http://www.fao.org/countryprofiles/ index/en/?iso3=JOR (accessed on 8 March 2021).

70. Rajsekhar, D.; Gorelick, S. Increasing drought in Jordan: Climate change and cascading Syrian land-use impacts on reducing transboundary flow. Sci. Adv. 2017, 3, e1700581. [CrossRef] [PubMed] 
71. Al-Bakri, J.; Salahat, M.; Suleiman, A.; Suifan, M.; Hamdan, M.; Khresat, S.; Kandakji, T. Impact of climate and land use changes on water and food security in Jordan: Implications for transcending "The tragedy of the Commons". Sustainability 2013, 5 , 724-748. [CrossRef]

72. United Nations World Food Program Mobile Vulnerability Assessment and Mapping (mVAM) July/August 2020. Jordan Food Security Update- Implications of COVID-19. Available online: https: / /www.wfp.org/publications/jordan-food-security-updateimplications-covid-19-july-aug-2020 (accessed on 7 March 2021).

73. Note, A. The Role of Food and Agriculture for Jop Creation and Poverty Reduction in Jordan and Lebanon. World Bank Agricultural Sector Note(p166455) 2018. Available online: http:/ / documents1.worldbank.org/curated/ar/325551536597194695 /pdf/Agricultural-Sector-Note-Jordan-and-Lebanon.pdf (accessed on 7 March 2021).

74. Jordan Investment Commission (JIC). Agriculture Sector Profile 2017. Available online: https://www.jic.gov.jo/wp-content/ uploads/2018/07/Sector-Profile-Agriculture-Final-Mar-2018-JIC-HAS-020418--1.pdf (accessed on 8 March 2021).

75. OECD/FAO. OECD-FAO Agricultural Outlook 2018-2027; OECD/FAO Publishing: Rome, Italy, 2018. Available online: http: / / www.fao.org/documents/card/en/c/I9166EN (accessed on 9 March 2021).

76. Department of Statistics (DoS). Household Expenditures \& Income Survey. Available online: http://dosweb.dos.gov.jo/ economic/expenditures-income/expend_tables/ (accessed on 26 December 2020).

77. World Bank. Jordan Housing Sector Review Report P158331. 2018. Available online: http:/ / documents1.worldbank.org/curated/ en/855101555960778525/pdf/Jordan-Housing-Sector-Assessment-Housing-Sector-Review.pdf (accessed on 8 March 2021).

78. Simpson, C.; Abo Zayed, A. New Faces, Less Water, and a Changing Economy in a Growing City: A Case Study of Refugees in Towns, Irbid, Jordan. Available online: https:/ / www.refugeesintowns.org/irbid (accessed on 11 November 2020). 